\title{
HVORDAN SELGE DEN AMERIKANSKE DRØMMEN TIL ARABEREN I GATA?
}

Etter II. september prøver USA å gjenopprette sitt image i den arabiske verden. Merkevaren "Amerika” skal selges gjennom Al-Jazeera og arabiske medier. Budskapet er "frihet". Tine Ustad Figenschou (f.1976) skriver hovedfagsoppgave om AlMen noe har gått galt ... Jazeera i journalistikk hovedfag ved UiO, er vitenskapelig assistent på Journalisthøgskolen i Oslo og frilansjournalist tilknyttet Dagbladets kulturavdeling. 
TEKST: Tine Ustad Figenschou

"HOW DO I RESPOND when I see that in some Islamic countries there is vitriolic hatred for America? I' 11 tell you how I respond: I' $m$ amazed", sa president George W. Bush, under en pressekonferanse i Det hvite hus, II. oktober 200I. Han forsatte: "I' $m$, amazed that there is such a misunderstanding of what our country is about, that people would hate us ... Like most Americans, I just can't believe it. Because I know how good we are, and we' ve got to make a better job of making our case." Han hadde en stor oppgave foran seg, for til tross for at mange arabere beundrer amerikanske idealer som demokrati, ytringsfrihet og personlig frihet, mener mange at USA gjennom sin utenrikspolitikk i regionen ikke etterlever idealene. usa har lenge oversett den folkelige misnøyen fordi USA-vennlige under- trykkende regimer satt med makten og oljen flommet inn. For å motarbeide terrorangrep er det ikke lenger tilstrekkelig å overbevise eliten i de arabiske landene, fordi eliten ofte har syns-punkt fjernt fra “araberen i gata”. Det ble klart at for å vinne "araberens hjerte og tanker" må amerikanske myndigheter snakke direkte til den arabiske opinionen gjennom de massemediene som er populære $i$ arabiske land. Offentlig diplomati har derfor fått en sentral posisjon innenfor amerikansk sikkerhetspolitikk. ${ }^{1}$

Offentlig diplomati defineres som offisielle, statlig støttede programmer for å forstå, informere og påvirke folkeopinionen $\mathrm{i}$ andre land, gjennom kanaler som trykte publikasjoner, filmer, kulturutveksling, radio og fjernsyn. ${ }^{2}$ Den amerikanske debatten rundt offentlig diplomati etter II. september viste at flere politiske strateger mener det største problemet er mangel på informasjon. Den rådende oppfatningen er at USAS fiender hater USA fordi de ikke vet bedre, fordi usA er misforstått i utlandet. Med dette utgangspunktet hentet State Department inn mangeårig markedsføringsdirektør Charlotte Beers, for å nå publikum i islamske og arabiske land og motprogrammere Talibans og Al-Qaidas propaganda. Beers skulle bruke sine kunnskaper og erfaringer fra karrieren på Madison Avenue til å gjøre "Amerika" til en like sterk merkevare som McDonalds eller Coca Cola. ${ }^{3}$ Hele Beers arbeid bærer preg av hennes markedsføringsbakgrunn: Hun forsøker å bygge merkevaren "Amerika”, som hun skal selge til målgruppen "unge arabere og muslimer" gjennom å fokusere på et enkelt budskap som oppsummerer "den amerikanske drømmen".

Hvordan lykkes denne amerikanske 
offensiven mot arabiske medier? Hvilke utfordringer møter de og hvilke krefter motvirker arbeidet?

\section{Arabisk kommunikasjonsrevolusjon}

Den amerikanske offensiven må tilpasses et regionalt kommunikasjonsklima som de siste årene preges av to nye trekk. Det er en konfliktarena der amerikanske talspersoner må forsøke å imøtegå Osama bin Ladens forsøk på å påvirke mediene og opinionen i regionen. Samtidig er mediemiljøet i økende grad åpent på grunn av framveksten av regionale aviser, internett og satellittkanaler. I Midtøsten og Nord-Afrika er fjernsyn det mest populære mediet, og de siste årene har seerne prioritert de arabiske satellittkanalene. Arabiske medier har lenge vær preget av statlige monopoler der monotone nyhetsopplesere viste bilder av statsledere som håndhilste, men ikke sendte direktesendinger, debatter, reportasjeinnslag eller kritiske innslag i frykt for å fornærme myndighetene. Fjernsyn har vær det mest sensurerte og kontrollerte mediet. Nå er bildet endret. Al-Jazeera, som ble startet av den reformvennlige emiren i Qatar i I996, er en av flere arabiske satellittkanaler som er lansert av arabiske myndigheter og entreprenører de siste årene. Flere arabiske stater, som var vitne til CNNs internasjonale innflytelse under Golfkrigen i I99I, forsto hvor viktige 24-timers satellittkanaler var for publikums bilde av krigen. De anså satellittkanaler som strategisk viktige og lanserte egne satellittnettverk etter krigen.

Al-Jazeera tiltrakk seg raskt stor oppmerksomhet: Kanalen omtalte sensitive tema, sendte kontroversielle debatter og direktesendinger fra store nyhetshendelser, og etter hvert har også kanalens arabiske konkurrenter fått en mer pågående politisk journalistikk gjennom en rekke talkshow, debatter og samfunnskommentarer. De fleste ekspertene er enige om at Al-Jazeera har spilt en viktig rolle $i$ å mobilisere til massiv støtte for den andre palestinske intifadaen høsten 2000. Ikke siden I970tallet har så mange arabere sett og hørt ett enkelt massemedium, dekningen har flere steder utløst pro-palestinske demonstrasjoner og kanalen har økt mobiliseringen i den arabiske opinionen. ${ }^{4}$ Al-Jazeera ble kjent blant vestlige medier og statsledere under "krigen mot terror" høsten 200I. Gjennom en rekke eksklusive intervjuer med Osama bin Laden og dekningen fra de Taliban-kontrollerte områdene i Afghanistan ble de en viktig bidragsyter for internasjonale medier. Mange vestlige kommentatorer har kritisert Al-Jazeera for å være pro-palestinske, anti-israelske og anti-amerikanske. Kanalens dekning fra krigføringen i Afghanistan var også kontroversiell, men Al-Jazeera gienspeiler den arabiske opinionen, og har et språk og en form som den arabiske opinionen kan relatere seg til.

\section{Osama bin Ladens mediestrategi}

"Hvordan kan en mann i en hule utkommunisere verdens ledende kommunikasjonssamfunn?" spurte UsAs tidligere FN-ambassadør Richard Holbrooke høsten 200I. ${ }^{5}$ Bare timer etter krigsutbruddet 7. oktober avbrøt CNN krigsdekningen for å sende et Al-Jazeera-innslag med verdens mest ettersøkte mann Osama bin Laden og usAS største fiende snakket for første gang direkte til det amerikanske folk. Terrormistenkte Osama bin Laden hadde en effektiv og tilsynelatende gjennomtenkt mediestrategi. For å nå sine to viktigste målgrup- 
per, vestlige nyhetsmedier og de arabiske massene, gikk bin Laden via Al-Jazeera. Talen 7. oktober var den første av flere videotaler, båndopptak og uttalelser gitt av medlemmer av Al-Qaida-nettverket som ble sendt eksklusivt på Al-Jazeera. Det er tre tema som går igjen i Osama bin Ladens retorikk før og etter terrorangrepene: a) Verden er delt mellom "de troende" og "de vantro", de som er med og de som er mot Guds vilje, b) Fienden er UsA, Israel og supermaktenes allierte blant muslimene,

\section{For å motarbeide terrorangrep} er det ikke nok å overbevise eliten $i$ de arabiske landene.

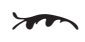

og c) Han kjemper en forsvarskrig mot 80 års amerikansk undertrykkelse $\mathrm{i}$ den islamske verden (viser til døende spedbarn i Irak, okkupasjonen av Palestina, urettferdigheten i Kashmir og brutaliteten i Tsjetsjenia), og hans vilkår for å slutte krigen er å frigjøre Jerusalem og den arabiske halvøy. ${ }^{6}$ For mange unge mennesker i regionen, med få muligheter, lite håp om en bedre framtid og en sterk følelse av å være ekskludert fra overflodssamfunnet, kan Osama bin Laden oppfattes som en helt som setter ord på forfølgelsen, utelukkelse, nedverdigelsen, ydmykelsen og undertrykkelsen de selv føler på kroppen. Det er en bred folkelig støtte for budskapet om at USA og vestlige myndigheter giør livet vanskelig for arabere og muslimer. Det er en forenkling å dele verdens muslimer i to grupper - de mange moderate og de få ekstreme - for det finnes også mange tvilere. Denne gruppen er i utgangspunktet motstandere av terroraksjoner, men dersom terroren blir besvart med det de oppfatter som vestlig maktarroganse og undertrykking kan denne gruppen bevege seg mot ekstremismen. De unge tvilerne er derfor målgruppen for USAS offensiv.

\section{Amerikanske krisetiltak}

Umiddelbart etter II. september etablerte amerikanske myndigheter flere mediesentre for å effektivisere kommunikasjonen med amerikanske og internasjonale medier, og alle offisielle uttalelser ble oversatt til 30 språk. For å svare på Talibans daglige pressekonferanser etablerte amerikanske og britiske myndigheter et 24-timers mediesenter i Pakistan, etablerte et nettsted for å vise terrornettverket Al-Qaidas grusomheter og laget en informasjonsbrosjyre om nettverket som ble publisert på 36 språk. I tillegg etablerte amerikanske strateger flere multimedierom, økte antallet arabiske utvekslingsstudenter til USA $^{7}$ og trappet opp nettverksjobbingen med tidligere studenter i usa. Både eksisterende arabiske medier og nye amerikanske kanaler rettet mot et arabisk publikum ble viktige kanaler for å få ut det amerikanske budskapet til "araberen i gata”. Flere meningsmålinger viste at muslimer og amerikanere flest deler flere kjerneverdier og er opptatt av de samme temaene i dagliglivet: familie, jobb og tro ${ }^{8}$ og Beers satte i gang annonsekampanjer og produksjon av TV- og radioprogram (for arabiske medier) som fokuserte på disse felles verdiene. Mest oppmerksomhet fikk minidokumentarene kalt "Muslim Life in America” der fem muslimer bosatt i usA forteller om sine liv og verdier. Serien framstiller usa som et multikulturelt og tolerant 
samfunn, og motvirker på denne måten forestillingene av usA som anti-muslimsk. Det hadde lenge vært klart at Voice of America (voA) Arabic trengte fornyelse siden kun to prosent av befolkningen i Midtøsten hørte på kanalen i september 200I.9 voA Arabic var særlig upopulær blant arabere under 25 år, og for å tilpasse det amerikanske arabiskspråklige radiotilbudet til den unge målgruppen relanserte amerikanske myndigheter kanalen som Radio Sawa ("sawa” er arabisk for "sammen”). “Sawa” spiller i hovedsak en blanding av arabisk og vestlig popmusikk, i tillegg til korte nyhetssendinger på arabisk og flere interaktive programkonsepter der lytterne selv deltar.

\section{USA og Al-Jazeera: Smiger og sensur}

Al-Jazeeras eksklusive tilgang til Al-Qaida ledelsen i Afghanistan og kanalens oppslutning blant arabiske seere tok amerikanske myndigheter og vestlige nyhetsmedier på senga. Bush-administrasjonen visste ikke helt hvordan de skulle reagere og har vekslet mellom å rose, fordømme, true og bombe kanalen. Storbritannias statsminister Tony Blair var den første statslederen som forsto viktigheten av å snakke på Al-Jazeera og ba kanalen om intervju kort tid etter bombestarten, et trekk som ble svært positivt mottatt blant arabiske seere. I midten av oktober prioriterte også Beers å få usAs viktigste talspersoner på Al-Jazeera og andre store arabiske medier. Utenriksminister Colin Powell, sikkerhetsrådgiver Condoleeza Rice og forsvarsminister Donald Rumsfeld er blant lederne som ga intervjuer på kanalen. Men de amerikanske representantene møtte store utfordringer på Al-Jazeera. Det viste seg vanskelig å styre intervjuene i “amerikansk retning”. Rice ble for eksempel stilt en rekke spørsmål om IsraelPalestina-konflikten (mens hun egentlig kom for å snakke om "krigen mot terror") og hennes pro-Israel-uttalelser ble sendt $i$ flere reklameinnslag i dagene fram mot

\section{Etter tiår med diskriminering har palestinerne loert: Man kan ikke selge den palestinske historien $i$ USA.}

selve intervjuet. Reklamene vekket sinne og fikk flere kommentatorer til å uttale at usA hadde tapt allerede før intervjuet ble sendt. Den største utfordringen for de amerikanske representantene var manglende språk- og kulturkunnskap: Svært få ledende amerikanske diplomater og talspersoner behersker arabisk så godt at de kan delta i debatter og intervjuer. Til tross for at Al-Jazeera tilbyr oversettere, er dette fremdeles ikke tilstrekkelig i en viktig ordkrig. Det finnes imidlertid noen positive unntak. Høsten 200I representerte tidligere ambassadør Chris Ross usA på de populære direktesendte debattprogrammene på Al-Jazeera og gjorde med sin karisma og evne til å velge de rette ordene (på flytende arabisk) et sterkt inntrykk på seerne. Men også Chris Ross mener han hadde problemer med å få fram budskapet sitt på grunn av det han mener er forutinntatte arabiske medier. Ross mener at AlJazeera riktignok inviterer flere eksperter, men at "alle" er anti-amerikanske, og at han alene må debattere mot det han karakteriserer som flere "anti-amerikanske ekstremister" i kanalens debatter og talkshow. ${ }^{\text {Io }}$ En annen viktig amerikansk strate- 
gi for å få egne synspunkter bedre fram i internasjonale medier er å bedre forholdet til utenlandske journalister og korrespondenter. Den amerikanske ekspertgruppen Independent Task Force on Public Diplomacy påpeker at amerikansk utenrikspolitikk lenge har planlagt sine informasjonsstrategier, taler, presseskriv og pressekonferanser for å tilfredstille de hjemlige amerikanske mediene, mens utenlandske korrespondenter ble oversett og nedprioritert. Gjennom å marginalisere utenlandske journalister har amerikanske myndigheter gått glipp av en viktig og effektiv kanal til å få sine budskap ut i utenlandske medier." Statssekretær Beers tok umiddelbart fatt i problemet og arrangerte flere "smøreturer" for å lære opp og påvirke arabiske og muslimske journalister, men fremdeles nekter mange politikere i Washington å snakke med Al-Jazeera. Kanalens korrespondent i Washington D.C. har flere ganger uttalt at han trygler og ber de amerikanske myndighetene om å uttale seg til det arabiske publikum gjennom AlJazeera uten å oppnå resultater. ${ }^{12}$ Det har også vært et problem at de talspersonene som faktisk uttaler seg snakker som en "supermakt", med et språk og en tone som ikke appellerer til den arabiske målgruppen.

Til tross for iherdige forsøk på å få fram amerikanske synspunkt på Al-Jazeera, ble deler av den amerikanske administrasjonen etter hvert så kritiske til kanalens dekning at de ved flere anledninger forsøkte å presse qatarske myndigheter til å sensurere og moderere kanalen. Allerede i slutten av september 200 I beskyldte USAS ambassadør i Qatar Al-Jazeera for å ha en ubalansert dekning av hendelsene Ir. september og for å oppfordre til anti- amerikanske følelser i Midtøsten. 3. oktober uttalte emiren av Qatar, Sheikh Hamad bin Khalifa el-Thani, som også er den største eieren av kanalen, at amerikanske myndigheter hadde bedt ham om bruke sin autoritet til å påvirke kanalens dekning i en mer UsA-vennlig retning. Emiren opplyste videre at han hadde avfeid oppfordringen og ikke ville gripe inn i Al-Jazeeras redaksjonelle politikk. Åttende oktober klaget amerikanske myndigheter igjen på AlJazeeras dekning etter at Osama bin Laden i sin Tv-tale hadde advart UsA om at "Amerika skulle leve i frykt". En ansatt i State Department forklarte at usa beskytter ytringsfriheten, men frykter at Osama bin Laden skal kunne bruke mediene til å spre sine voldelige ideer. ${ }^{13}$ En annen årsak til amerikansk frustrasjon over Al-Jazeera var kanalens fokus på sivile tap og skader i Afghanistan. Al-Jazeera viste hyppige nærbilder av lidelse og død og vektla at ødeleggelsene var forårsaket av amerikanske styrker, noe amerikanske myndigheter mente økte usa-hatet. Forsvarsminister Donald Rumsfeld kalte kanalens dekning for "terroristenes mikrofonstativ", karakteriserte dekningen som propagandistisk og anklagde kanalen for å fabrikkere bilder av sivile tap. ${ }^{14}$ De amerikanske forsøkene på å tvinge Al-Jazeera til stillhet møtte sterk kritikk i Midtøsten. Flere medieanalytikere har trukket fram truslene som et eksempel på hvor klønete den amerikanske informasjonskrigen på mange måter har vært. Det er ikke første gang Al-Jazeera blir forsøkt stanset, men de amerikanske forsøkene møtte svært negative reaksjoner i Midtøsten nettopp fordi de ble et symbol på amerikansk dobbeltmoral.

Umiddelbart etter terrorangrepene kjempet vestlige nyhetsmedier om den 
beste avtalen med Al-Jazeera, og CNN vant første runde. Bare dager etter terrorangrepene ble en samarbeidsavtale inngått mellom de to kanalene der CNN fikk eksklusive rettigheter til å sende stoff fra Al-Jazeera og tilgang til de Taliban-kontrollerte områdene gjennom Al-Jazeeras korrespondenter, mens Al-Jazeera fikk bruke CNN-stoff fra områdene kontrollert av Nordalliansen (der arabiske journalister var uønsket). De amerikanske mediene ble imidlertid gradvis mer patriotiske. Siden Al-Jazeera ikke kunne stanses gjennom diplomatisk press mot myndighetene i Qatar, henvendte president Bushs sikker-

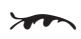

\section{Etter tiår med diskriminering har} palestinerne loert: Man kan ikke selge den palestinske historien i USA.

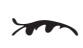

hetsrådgiver Condoleeza Rice seg også til sine hjemlige amerikanske medier. Rice ba dem avstå fra å sende bilder fra Al-Jazeera der bin Laden talte til sine tilhengere for å unngå at terroristene sendte hemmelige meldinger til terrorceller ute $\mathrm{i}$ verden. I første omgang ba Rice de fem største TVnettverkene, ABC, CBS, CNN, NBC og Fox, om å ikke sende innslag med Osama bin Laden eller hans medarbeidere uten å se noye gjennom tapene først og å begrense antallet repetisjoner av innslagene. Ledelsene lovte å rette seg etter Rices forslag og senere samtykket også de største avisene i å ikke trykke transskripsjoner av bin Ladens taler.

Flere kommentatorer og ytringsfrihetsorganisasjoner reagerte på denne selvsensuren og aksepten av myndighetenes begrensninger. ${ }^{15}$ Al-Jazeeras Kabul-kontor ble ødelagt av en amerikansk rakett i3. november 200I - bare timer før Nordalliansen inntok byen. Kabul-korrespondent Tayseer Allouni og hans medarbeidere forlot hovedkvarteret bare minutter før det ble truffet. Ifølge talspersoner for Al-Jazeera var kontorets beliggenhet kjent for amerikanske styrker og angrepet var dermed enten en feilbombing eller et regelrett angrep på kanalen. Det er vanskelig å avgiøre om angrepet på kontoret var en fatal feil eller planlagt sabotasje, men flere kommentatorer mener bombingen var målrettet. ${ }^{16}$

\section{I hvor stor grad har de lykkes?}

Det er vanskelig å måle effekten av offentlig diplomati. Det er mulig å måle endringer i folkeopinionen over tid, men det er likevel vanskelig å konkludere med at en faktor eller ett sett faktorer er utslagsgivende. Det er imidlertid lite som tyder på at den brede folkelige skepsisen mot amerikansk utenrikspolitikk har minket siden satsningen startet etter II. september. I sine siste uttalelser vektla også statssekretær Beers at det arabiske publikummet var preget av en kynisme, at "salget" av Amerika "gikk litt tregt", og hun ba politikerne om å ha et langsiktig perspektiv på strategien. Blant de omfattende tiltakene satt i gang under Beers er det Radio Sawa som har hatt størst suksess. Kanalen har fått mange lyttere blant unge arabere. Kritikerne peker likevel på at selv om mange unge elsker popmusikken, stoler de ikke på Sawas nyhetssendinger og oppdaterer seg på nyheter i andre kanaler. ${ }^{17}$ Det var også høye forventninger til minidokumentarene om muslimer i usa. Beers planla i utgangspunktet å sende "Muslim Life 
in America” på Al-Jazeera og andre større arabiske satellittnettverk, men i oktober 2002 brøt forhandlingene med Al-Jazeera sammen fordi kanalen ifølge usa krevde for mye penger. Det har også vært store vanskeligheter med å sende minidokumentarene $\mathrm{i}$ andre arabiske land som ikke ønsker denne typen "politisk propaganda" og State Department besluttet derfor å utsette kampanjen på ubestemt tid. Det må karakteriseres som et nederlag for de amerikanske strategene at ikke et eneste arabisk land har sendt minidokumentarene, som kun er vist $i$ Indonesia. ${ }^{18}$

'Tilhengerne av statssekretær Beers' revitalisering av offentlig diplomat karakteriserer hennes innsats som nytenkende og frisk på et vanskelig område. Støttespillerne mener det forverrede amerikanske imaget i Midtøsten ikke kan klandres Beers, men UsAs generelle utenrikspolitikk i Irak- og Palestina-spørsmålet. De vektlegger det vanskelige utgangspunktet Beers hadde da hun skulle "gjenopplive” et offentlig diplomati som siden den kalde krigen hadde blitt nedprioritert økonomisk og politisk. Men kritikerne, og de var i flertall, karakteriserer henne som en outsider som på grunn av sin manglende diplomatiske erfaring ikke mestret det byråkratiske spillet og dermed forsinket de viktige kampanjene. Andre stilte spørsmål ved om markedsføringsbakgrunn var den rette ekspertisen for oppgaven. Flere kommentatorer konkluderer med at UsA taper ordkrigen i arabiske medier, og det har kommet en rekke forslag til alternative strategier for å kommunisere mer effektivt med den arabiske opinionen.

Det alternativet Bush-administrasjonen ser ut til å prioritere framover er en amerikansk arabiskspråklig kanal ̃ foreløpig kalt The Middle East Television Network (METN) - som etter planen skal gå på lufta i 24-timer i 22 arabiske land. METN, som skal starte sendingene ved utgangen av 2003, er en direkte motprogrammering til Al-Jazeera. Amerikanske myndigheter har satt til side om lag 80 millioner amerikanske dollar til arbeidet med den nye kanalen. Kanalen skal sende "amerikanske" morgensendinger, sport, nyheter og barnesendinger, men understreker at kanalen ikke skal drive amerikansk propaganda og er "en uavhengig nyhetskanal”. Målsetningen med kanalen å motvirke de negative bildene av USA som sendes på arabisk Tv, å dempe oppfordringene til vold, å motvirke hatsendinger på radioen og å motvirke journalistisk selvsensur. ${ }^{19}$

Hvilke overordnede utfordringer og problemer møter den amerikanske strategien?

Det er grunn til å stille spørsmål ved flere sider av den amerikanske strategien. Et spørsmål som umiddelbart reiser seg er om amerikanske myndigheter virkelig forstår målgruppen? Det kan se ut som om amerikanske strateger ikke forstår hvordan og hvorfor den arabiske folkeopinionen er så kritiske til usA. For at usA skal engasjere målgruppen må de skaffe seg bedre kunnskap til arabisk kultur, og kunnskap om deres religion og tradisjoner. Som vist ovenfor er det nettopp Osama bin Ladens evne til å forstå og formulere folkets opplevde frustrasjoner som gir han popularitet, også blant de unge som er motstandere av terror og vold. Beers har samarbeidet tett med flere arabisk-amerikanske institusjoner og organisasjoner, men mangler likevel ekspertise som på den ene siden kjenner amerikansk politikk og 
offentlig diplomati, og på den andre siden behersker arabisk språk, kultur og politikk. Det andre sentrale spørsmålet er om de amerikanske strategene har den nødvendige troverdigheten som får folk til å tro på dem? Selv det mest gjennomtenkte argument vil falle dersom tilhørerne ikke stoler

\section{Etter tiår med diskriminering har} palestinerne loert: Man kan ikke selge den palestinske historien i USA.

på kilden, og denne mistroen er en stor utfordring for amerikanske myndigheter. Etter flere år med statlig styrte medier og propaganda har opinionen i Midtøsten utviklet en genuin skepsis til mediene, og denne skepsisen er ekstra sterk når det er amerikanske myndigheter som står bak. For å kommunisere bedre med "araberen $\mathrm{i}$ gata” forsøkte derfor Beers å gi amerikanske muslimer hovedrollen i minidokumentarene og andre informasjonsoppdrag, men dette kamuflerte likevel ikke at det var amerikanske myndigheter som var regissøren og filmene ble dermed mottatt som amerikansk propaganda.

Det viktigste spørsmålet blir likevel i hvilken grad det er mulig å selge merkevaren USA samtidig som landet driver den politikken de gjør i regionen? Flere kommentatorer påpeker at den amerikanske kommunikasjonsstrategien ikke kan bli effektiv dersom den ikke samsvarer med landets faktiske utenrikspolitikk. Kritikerne peker på at USAS største problem i forsøkene på å redefinere merkevaren "Amerika" i regionen, nettopp er dobbeltkommunikasjonen mellom offentlig diplomati (med budskap om "frihet") og utenrikspolitikken (krigføring i Afghanistan og senere Irak). Den amerikanske mediekommentatoren Bob Garfield formulerer dette paradokset på en god måte. Han skriver at så lenge den amerikanske strategien går ut på a) å vinne hjertene og tankene til "våre muslimske brødre og søstre" giennom å uttrykke sympati og forståelse, b) å arrestere "våre muslimske brødre og søstre" og holde dem i fengsel i månedsvis uten tiltale, og c) å bombe resten av "vår muslimske familie" til helvete - er det liten mulighet for å overbevise målgruppen. Flertallet i den muslimske verden ønsker at USA skal stanse sin støtte til Israels okkupasjon, gi dem muligheter for demokratiske valg (i stedet for de undertrykkende amerikanskstottede regimene mange av dem lever i) og muligheter for å komme seg ut av fattigdommen og håpløsheten. Hvis ikke disse prioriteringene inkluderes i amerikansk politikk vil "den amerikanske merkevaren" kanskje aldri appellere til målgruppen. ${ }^{20}$

\section{Epilog}

Har amerikanerne bombet sitt eget image?

I mars 2003 forlot Charlotte Beers stillingen som Undersecretary for Public Diplomacy and Public Affairs, angivelig på grunn av helseårsaker. Flere diplomater fortalte imidlertid amerikanske medier at hun fikk sparken på grunn av manglende resultater og intern kritikk. Beers ba om at hennes innsats skulle vurderes ut fra hvordan hun hadde revitalisert administrasjonens offentlige diplomati, og ikke først og fremst ut fra verdensopinionens raseri og motstand mot krigen i Irak. ${ }^{21}$ Uansett 
årsaken til Beers' avgang kom den på et svært ubeleilig tidspunkt for amerikanske myndigheter, bare et par uker før det amerikanske angrepet på Irak satte i gang. usA har store problemer med å framstille amerikanske militære kampanjer som humanitære, og mye av amerikanernes troverdighet i regionen avhenger av i hvilken grad de amerikanske forsøkene på å innføre demokrati i Irak vil lykkes. Det amerikanske offentlige diplomatiet er inne i en kritisk fase hvor utfordringene vokser i takt med det irakiske kaoset. Amerikanerne må endre sin politikk i regionen rundt viktige symbolsaker hvis det offentlige diplomatiet skal være effektivt. Et trekk ved den seneste utviklingen kan illustrere dette: I sitt arbeid for å vinne den irakiske opinionen har amerikanske og britiske myndigheter produsert flere TV-sendinger med appeller og taler til den irakiske sivilbefolkningen, men så lenge irakerne ikke har strøm, kan de ikke se på Tv.

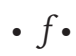

I Leonard, Mark og Conrad Smewing 2003:6, "Public Diplomacy and the Middle East - Introduction and Executive Summary", Foreign Policy Centre

2 U.S. Department of State, Dictionary of International Relations gjengitt på Public Diplomacy Website

3 Becker, Elizabeth 200I, "A special report: In the War on Terrorism, A Battle to Shape Opinion”, The New York Times II.II.200I, Tilgjengelig: http://query.nytimes. $\mathrm{com} / \mathrm{search} /$ article-printpage.html? res $=9$ Do5EFDE I238 $932 \mathrm{~A} 2575$

4 El-Nawawy, Mohammed og Adel Iskandar 2002:56, “AlJazeera", Cambridge, Mass.: Westview

5 Council of Foreign Relations (2003), "Public Diplomacy", Terrorism: Questions \& Answers. Min oversettelse. Tilgjengelig: www.terrorismanswers.com/responses/ diplomacy2.html

6 Vogt, Kari og Anders Heger 2002:I7I, “Bruddet. Hellige krigere og en ny verdensorden”, J. W. Cappelen Forlag, Oslo

7 Leonard, Mark (2002), "Diplomacy by Other Means” i Foreign Policy, september/oktober 2002
8 Se for eksempel Arab American Institute 2002, "As America Prepares for War With Iraq, New Study Defines Commonalities/Differences Between Arabs and Americans", pressemelding 8.10.2002, Tilgjengelig: www. aaiusa.org/pr/releaseIo-o8-02.htm

9 Boehlert 200I

Io Ross, Chris (2002), i samtale med Sarah Sullivan, Transnational Broadcasting Studies No 9, høst/vinter 2002. Tilgjengelig: www.tbsjournal.com/Ross.html

II Independent Task Force Report (2002), "Public Diplomacy: A Strategy to Inform", Report of an Independent Task Force on Public Diplomacy Sponsored by the Council of Foreign Relations. Tilgjengelig: www.cfr.org/PublicDiplo macy_TF.html"

I2 Sullivan 200I

I3 Levy, Alexandre og Francois Bugingo (200I), "United States: between the pull of patriotism and self-censorship. The US media in torment after II September", Reporters Without Borders II.IO.200I. Tilgjengelig: www.rsf.fr/arti cle.php3?id_article=2533\&var_recherche=USA+after+sep tember+IIth

I4 El-Nawawy og Iskandar 2002:I80

I5 Navasky, Victor (2002), "Foreword” i Barbie Zelizer og Stuart Allan (red.) "Journalism After September II”, Routledge, London og New York

I6 Se for eksempel Ottosen, Rune (2002a), "Pressefriheten under press etter II. september", i Stig Finslo (red.) "Redaktørforeningens årbok 2002", Høyskoleforlaget, Kristiansand

I7 Fandy, Mamoun (2003), i samtale med Terence Smith på PBS, Online NewsHour januar 2003. Tilgjengelig: www.pbs.org/newshour/media/public_diplomacy/ fandy_I-03.html

I8 ibid.

I9 Pattiz til Burkeman, Oliver (2003), "Arab world now faces invasion by American TV" (min oversettelse), The Guardian 24.04.2003. Tilgjengelig: http://media. guardian.co.uk/Print/0,3858,4653973,00.html

20 Garfield, Bob (2002), "State Department Propaganda Spots Are Naí ve”, AdAge.Com 25.II.2002. Tilgjengelig: www.adage.com/news.cms? newsId $=36618$

2I Beers til Teinowitz, Ira (2003), "Charlotte Beers to resign From State Department", AdAge.Com 03.03.2003. Tilgjengelig: www.adage.com/news.cms?newsId $=37278$ 